\title{
L2 Acquisition Portrayed through the Use of Way Ahead Game by Children in Learning Basic English
}

\author{
Angga Apresa Nuryasin \\ apresan19@gmail.com \\ Universitas Teknokrat Indonesia
}

\begin{abstract}
This research investigates how students learn Basic English by using Way Ahead game. This study was conducted to identify how effective the use of educational game in acquiring L2 is. Qualitative study was used by the researcher as the research method. The data were collected through conducting several interviews and exploring library study. The case study involved 4 elementary school students as the participants. The background of the research on the role of game in learning L2 is based on Fuscard (2001) and Boyle (2011). The findings of this research are 4 most important roles of game implementation in learning process: (1) pedagogical device, (2) creative ice breakers, (3) engaging students, (4) helping students retain salient points in our teaching. The purpose of the research is to give information over the portrayal of using educational games in learning which is expected to give practical use in teaching Basic English to children as their L2 acquisition.
\end{abstract}

Key Words: L2 acquisition, basic English, Way Ahead game

\section{Introduction}

Being good at English in both speaking and writing is essential these days for it has been attached to the most aspects in life from daily activities until working businesses. In recent years, English has been considered as one of the most popular languages. It is now the key factor of globalization- of political views, international business as well as education (Johnson, 2009). Learning English is surely essential nowadays since speaking and writing ability are needed to understand the meaning of our communication, especially with foreigners. Learning English is valuable due to the use of the language is extremely broad today which obliges every learner to recognize the communication to gain the needed information.

Learning is to know new things; to increase our knowledge, it is kind of we start with a small bag, the more we live, the more we fill it up (Säljö, 1979). This research also lies on the background of learning conceptions described by Säljö as listed below:

a) Learning as the increase of knowledge.

b) Learning as memorizing.

c) Learning as the acquisition of facts, procedures etc., which can be utilized and retained in practice.

d) Learning as the abstraction of meaning.

e) Leaning as the interpretative process aimed at the understanding of reality.

Furthermore, learning has also been defined as a change in human disposition or capability that persists over a period of time and is not simply believed as processes of growth (Gagne, 1965). Moreover, Ambrose, et al. (2012) defined learning as a process that leads to change, which occurs as a result of experience and increases the potential of improved performance and future learning.

Like first language acquisition, second language acquisition proceeds by stages and is characterized by developmental orders (Little, 2001). Figueroa Flores (2015) stated that "one major competence for learners in the 21 st century is acquiring a second language (L2)." and added "As the 21 st century moves forward, the field of second language learning and instruction has become more technology oriented". L2 refers to a second language or a language that is being studied. Learning L2 means studying foreign language either for the sake of knowledge or for real life application. The process of learning that is mostly digitalized in recent years makes the demand of mastering or at least being familiar to technological devices becomes urging especially for L2 learners.

On the other hand, Basic English is the understanding target of the learner in this research. Basic English is a copyrighted system of simplified English which is consisting of the 850 words considered as most essential and of a short list of grammatical rules and designed to serve both as an auxiliary language and as an introduction to English itself (Webster, 2017). The definition is also supported by Collins (2018) that stated Basic English is a 
simplified form of English proposed by C.K. Odgen and I.A. Richards, containing a vocabulary of approximately 850 of the most common English words, intended as an international language.

As the aid of the research, an offline game for PC is utilized. The game is Way Ahead by Ron Holt, et al., and Macmillan Education as the publisher. This game was first published in 1999 in form of textbook which then created to be a PC game in 2001. There are 6 series of practices in Way Ahead game. They practice and support the grammar and vocabulary taught in Way Ahead. Way Ahead has helped children in over 40 countries to learn English. At the lower levels, the books introduce a cast of interesting characters who contextualize the language and make it fun. In the upper levels, new language is presented through a series of motivating and informative topics (Mary Bowen and Printha Ellis; two of the authors). The purpose of the course is to develop the skills that the children need to pursue their studies to a higher level.

According to Holt (2001), the uses of the game are as interaction and improvement tools. Additionally, the functions of this game are to educate and to entertain. The game is educative for it contains numerous materials related to English basic lessons and grammar which every English learner needs to understand, such as numbers, plural-singular, vocabularies, etc. This game is also entertaining since it presents attractive pictures of cartoons and animations to avoid the feeling of boring in the learning process for 5 until 13 year-old players.

\section{Research Method}

\section{Data Analysis}

This research discussing the students' opinion towards how the use of Way Ahead game affects their learning process was conducted to provide the readers information about the role of educational game in learning English and as a previous study to be used by another researcher when analyzing the related topics.

The results of the interviews were processed through identifying, transcribing, interpreting, and categorizing, and concluding the answers given by the students to ease the readers to obtain and understand the data.

\section{Participants}

Four elementary school students as the researcher's private course students were involved in this research. The reason why the researcher chose the students was due to their different background of schools, behavior in learning, and ability in mastering Basic English lessons. Some of the students were able to understand the course materials easily and some are not.

\section{Instruments}

Interview was used as the medium of gaining the reliable data. This case study was conducted by interviewing the researcher's students. The nature of qualitative study is involved to find out the portrait of the students' learning process by using Way Ahead game as the studying aids.

\section{Procedure}

The researcher visited the students' houses as the routine of private teaching. Then, the students are asked several questions related their opinion towards the game, how they see the game as their studying aids how the game interest them, and what they can get from the game related to English things. The improvement is measured by monitoring their behavior in learning and ability in mastering English before and after using the game within the researcher's teaching hour.

The interview to the students spent approximately a week on May 18-23, 2018. Each interview lasted around 30 minutes after the students were asked to play the game as the ice-breaking of studying which then taught several Basic English lessons.

\section{Findings}

The results of the interviews over the students' opinion towards playing game as the tool for learning English as their second language are in the followings:

Question 1: Why do you want to learn English? (Pereira, 2016: The Essence of English)

KR: "Because I like English. it is also because in my school, English is the most obliged language to be spoken, we are obliged to speak English in some classes and we also get more English homework than other subjects.."

MD: "I want to speak English fluently because I want to be number one in my kindergarten!!" 
The answers of both students show the essence of English is supported to be performed in their learning environment.

Question 2: What is your problem in learning English? (Putra, 2015: Indonesian's Problems in Learning English)

AR: "Sometimes umm, I do not have any partner to study, uncle.. that makes me lazy to study like write the vocabularies that I should remember because I never practice them after course hour or school hour.. consequently, I forget most words I have learned and cannot move forward to the next lessons"

KN: "My problem is, how to say, like this uncle, I am afraid of making mistakes in speaking and writing English. I prefer being quiet instead of speaking with errors. It is shameful to speak with errors."

The problem of AR is more affected by external factors which not allow him to study outside classroom while KN's is internal that he is not brave to fail in his speeches while speaking.

Question 3: What do you think become your favorite thing to play? (Howard, 2015: Distracted by Technology: Focusing Attention on Homework)

MD: "I love to play slime! I bring it whenever I go. It is soft and sticky and interesting. I often search for slime on Google to buy and play it, always"

KR: "umm what ya?, uncle,, I always play my smartphone to open Instagram and play games. I always bring my phone with me to take pictures, to play game, open Instagram, and others.."

Both of MD and KR have the same distraction which is technological device or gadget. The use of the smartphone is so frequent that makes them always stick to it all the time including while studying.

Question 4: What do you think about the game? How does it help you in learning? (Mubaslat, 2011: The Effect of Using Educational Games on the Students' Achievement in English Language for the Primary Stage)

MD: "The game is very interesting for me. The cartoons are funny and attractive. I love to see pictures moving and colorful images.. so I feel easier to memorize the vocabularies and how to pronounce words in English! I like it, uncle!"

AR: "This game is simple to play, but I still have to focus on playing this game. I am interested in several units because they have a lot of animations. That is.. they help me to remember the words in the game.."

Both MD and AR agreed that the game is interesting to them and it helps them in learning Basic English. The game successfully attracts their attention as most games do to the children.

\section{Discussion}

Learning second language in early age is recommended to achieve better process. As stated in Krashen et al. (1979), learners who begin natural introduction to second languages during childhood generally achieve higher second language proficiency than those beginning as adults. In learning L2 effectively, teachers should consider proper methods to apply. Acknowledging better methods in teaching is the key to create students' understanding due to the incapability of the students to study monotonously in long term which makes the students get bored and lose their focus. Game use is chosen to be the better method in this research. The studying process should be aided by playing game to maintain the students' focus. The effectiveness of the game was measured through the students' opinions. Thus, the researcher transcribed the answers from the interviews to gain the information of how playing game in learning gives positive effect to the students' L2 acquisition.

The participants were initially asked about their reasons of learning English privately. The asked question is based on Pereira (2016) who stated in his research, The Essence of English, that English is not only an International Language but essential language for interpersonal communication across the world. The first student stated that besides her favorite, her motivation of learning English is due to her learning environment. She studies in a school that obliges her to master English. The statement of Pereira (2016) is supported by the firstly asked student's reason that she wants to be good at English to communicate well in her school. The secondly asked student stated that being the best in her kindergarten is her reason to learn English more since the kindergarten uses 
bilingual system in daily study. This answer also supports Pereira's statement which shows the purpose of the students in mastering English is to gain the best ability in communicating.

Secondly, the students were interviewed about their difficulty in learning English. The background used for the question is from Putra (2015) in his research; Indonesian's Problems in Learning English that says Indonesian learners have 2 major problems in English, they are external factor or the surrounding which motivates or demotivates the student to learn English and internal factor or the perspective of the student itself to see English whether as a benefit or a burden. The answer of the first student can be concluded that the motivation from his surrounding is lack. It is normal to be indolent to learn something not regarded by the society. Thus, external factor is believed to be his problem in learning English. The next student stated that his anxiety of making errors is his main problem. This is vital for this may stop the process of interaction in learning due to the loss of intention to study new things because when a learner is afraid of doing something, he or she will stop to try and learning is nothing without trying. Thereby, his main issue is believed to be internal factor to see English as a threat to be learned.

Next, the students were asked about their favorite things used in their daily life. This question is actually an implication to identify the distraction of the students while studying. This question was based on Howard (2015) in his blog: Distracted by Technology: Focusing Attention on Homework. As stated by Howard that it is more complicated case nowadays having the fact that students and their smart phones are inseparable. According to the answers of both students, smartphone is their favorite thing which is always be with them. At first glance it seems harmless, doing homework or studying while playing smartphones, texting or checking social media and other side activity of learning, but in fact it can actually impair the students in learning the material as well as lower test scores. Further proof, researches have shown that it is one of the worst study habits a student can develop. It is due to the instant access of media in smartphones that please them to search anything at will. Consequently, it makes the students distracted and put aside their learning activity. Thereby, Howard's statement about technology as a distraction is supported by the students' answers. On the other hand is this study, game is considered to be a learning aid instead of distraction.

Lastly, the third question was asked to the students related to their opinion towards the use of the Way Ahead game in learning. The question is based on Mubaslat (2011) in her research; The Effect of Using Educational Games on the Students' Achievement in English Language for the Primary Stage. Mubaslat stated that “...games have a good effect on improving the achievement for the primary stage and to create an interactive environment. It is recommended to use games since they are very effective especially for the primary stages in teaching a second language and games are helpful for the teacher as a procedure for language acquisition". The firstly asked student stated that the game is interesting with cartoon and animation features that ease her on practicing pronunciation and memorizing vocabularies. Mubaslat's theory of interactive environment created through playing game is supported by the student's answer where it proves that pronouncing words is a form of interactive environment. The secondly asked student also supported the theory by stating that the game helps him to remember the words. The effort on language acquisition is believed to be the proof of the supporting statement.

This research is conducted by interviewing only some students from different elementary schools in Jalan Pramuka, Bandarlampung as the participants. Thus, as its limitation, it cannot be used as the fundamental background to investigate higher levels related to the game use such as Senior High Schools and Varsities.

According to study background, this research meets four proves:

\section{Game as pedagogical device}

Fuscasrd's statement about game as a pedagogical device in learning is identified in this research. Pedagogy is method and practice of teaching, especially as an academic subject or theoretical concept. Pedagogical device is described as the ensemble of rules or procedures by the use of which knowledge is transformed into classroom talk, curricula and educational communication. In this research, the pedagogical device is considered as a teaching and learning method in form of classroom talk containing the use of an educational game in the process of learning second language. Way Ahead game can be used as an effective method by teachers to maximize the students' attention in learning. The method can be applied while teaching L2 to the students such as playing the game to attain more English vocabularies and proper pronunciation. The game has been proven to maintain the children's memories about certain words and expressions in English in which give positive effect to the students for further use. Moreover, it is believed to be an effective method of teaching for the teachers who are able to relate the game to the students' learning environment which needs English understanding. 


\section{Game as ice breaker}

Hoyle's research of result of game as creative ice breaker is proven effective to lift the students' awareness. An icebreaker is defined as an activity, exercise, or experience that is designed to break the 'ice' which means remove the tension at the first meeting to make the learning activity flexible and enjoyable. The stiffness usually limits interactions of a group of people who may or may not know each other. An icebreaker should be fun and entertaining. In teaching and learning activity, the icebreakers are commonly presented as a game to warm up the group by helping the members to get to know each other and focus on the lessons.

Brown (2002) suggests that language is acquired more easily if certain emotion factors are created, such as being mentally stable and not angry, anxious or bored. This means that positive attitude seems to be important in second language acquisition. The method of making game as a learning ice breaker was proven to be able to give positive emotion to the children in learning English. The game was played in the first 15 minutes of teaching and learning activity. The students were asked to play the game before the teacher moved to the real discussions. As the result, the students got entertained who then got interested in learning the next lessons.

\section{Game to engage students}

Hoyle's statement of result of game to engage students is shown in this research. The use of game is regarded as a force to play. The students are asked to play a game over and over. This feeling is exactly what the teacher wants to establish during instruction. The instruction is intended to create an emotional connection with the content and a desire to repeat the experience. This occurred in L2 acquisition by playing Way Ahead game. The students got the desire to play more and more units and use more English that made the more able to engage to the materials. The materials in Way Ahead game match the materials the teachers are about to give to the students. It gave the students the ability to engage the lessons by having to pay attention to the game if they want to understand the next lessons. Furthermore, it also gave the students awareness to engage with their partners (if any) to make the learning activity more interactive.

\section{Game to retain achievement}

Hoyle's result of game to help students in retaining achievements is supported by this research. This is supported by Al-Masri and Al-Najar (2014) whose research stated that students at the primary stage who get higher achievement of were attributed to the using of word games for teaching English vocabulary. The goal of the game used in this study is target essential academic content. It means games must focus on important academic content so that they will have proficient effect on student's achievement and make use of valuable classroom time. The most efficient way to maintain an academic focus especially in English is to provide and play games consisting important Basic English terms and phrases. It was proven by several benefits the students got after learning with the game. Based on the interviews, KN, a student who was difficult to speak up, is finally encouraged to state his opinions and answer some questions in English. KR, the gadget maniac, can make use of the game as her learning aid so that she can perform her English well and achieve the highest rank in English subject at school.

\section{Conclusion}

Having discussed about the game use, an interest creator and a helpful learning medium are the portraits of Way Ahead game use in children's L2 acquisition in learning Basic English. The role of Way Ahead game is proven functional for the students in learning Basic English. The game provides materials of Basic English as the students' lessons to acquire L2 comprehension. The positive feedback is obtained by the teacher for applying game as their method in teaching and the positive changes of the students' cognitive and motor skills are identified after playing the game, the students become more interested in acquiring English and active in learning activity which leads them to get achievements in their learning environment.

\section{References}

Al-Masri, A., Al-Najar, M. 2014. The effect of using word games on primary stage students achievements in English language vocabulary in Jordan. American International Journal of Contemporary Research Vol. 4, No. 9, pp. 144-152.

Anderson, J. (1983). Cognitive Psychology and Its Implications (2nd ed). New York: Freeman.

Buckingham, J. 2014. Open Digital badges for the uninitiated. The Electronic Journal for English as a Second Language Vol. 18, pp. 1-11. 
Boyle, Susan. 2011. Teaching Toolkit: An Introduction to Games Based Learning. Republic of Ireland: UCD Dublin.

Blackwell, L. S., Trzesniewski, K. H., \& Dweck, C. S. 2007. Implicit theories of intelligence predict achievement across an adolescent transition: A longitudinal study and an intervention. Child Development Vol. 78, pp. 246-263.

Brown, H. D. 2002. Principles of Language Learning and Teaching. White Plains, NY: Longman.

Cam, L., Tran, T. 2017. An Evaluation of using Games in Teaching English Grammar for First Year English Majored Students at Dong Nai Technology University. International Journal of Learning, Teaching and Educational Research Vol. 16, No. 7, pp. 55-71.

Figueroa-Flores, J. F. 2015. Using Gamification to Enhance Second Language Learning. Digital Education Review No. 27, pp. 32-54.

Gardener, R., Lambert, W. 1972. Attitudes and Motivation in Second Language Learning. Rowley, MA: Newbury House Publishers.

Gass, Susan M, and Selinker, Larry. 2008. Second language Acquisition: An Introductory Course. New York: Routledge

Gomez, Tiago. 2015. Computer Game Studies: Research and Educational Design. Universidade Federal de Minas Gerais: Brazil.

Granic, Isabela. 2013. The Benefits of Playing Video Games. Radboud University Nijmegen: American Psychologist Association.

Haystead, M. W., \& Marzano, R. J. 2009. Meta-Analytic Synthesis of Studies Conducted at Marzano Research Laboratory on Instructional Strategies. Englewood, CO: Marzano Research Laboratory.

Holt R., Hocking L., "Way Ahead: A Foundation Course in English”, Macmillan Education, vol. 2, pp.1-3.

Howard, Michael. 2015. Distracted by Technology: Focusing Attention on Homework. Needham, MA: BeyondBook Smart.

Krashen S., Long, M. and Scarcella, R. 1979. Age, rate and eventual attainment in second language acquisition. TESOL Quarterly Vol. 13, pp. 573-82

Little, David. 2001. Learning English as a Second Language: Acquisition and Instruction. Republic of Ireland: Integrate Ireland Language \& Training.

Mubaslat, Mania Moayad. 2012. The Effect of Using Educational Games on the Students'Achievement in English Language for the Primary Stage. Jordan: Amman

Piaget, J. 1962. Play, Dreams and Imitation. New York: Norton.

Putra, Meizi Nur. 2015. Indonesian's Problems in Learning English. Jakarta: Collaborative Research.

Taylor, B. 1983. Teaching ESL: Incorporating a communicative, student centered component. TESOL Quarterly Vol. 17, pp. 69-88.

Qvortrup, Ane. 2016. On the Definition of Learning. Denmark: University Press of Southern Denmark.

\section{Acknowledgement}

Many thanks to my students on Jalan Pramuka, Bandar Lampung, who have volunteered and given big cooperation to participate in answering the interviews and to one of my lecturer who has given me the game to be used in this research 